\title{
PERSEPSI GURU TERHADAP PENERAPAN KTSP DAN KURIKULUM 2013 DALAM MATA PELAJARAN BAHASA INDONESIA
}

\author{
Ummul Khair. Dana Prasetiana \\ Institut Agama Islam Negeri (IAIN) Curup \\ ummulkhair1213@gmail.com
}

\begin{abstract}
Abstrak: Penelitian ini dilatarbelakangi oleh perubahan kurikulum dari KTSP menjadi Kurikulum 2013 memberi anggapan yang berbeda-beda untuk setiap guru yang mengimplementasikannya karena KTSP dan Kurikulum 2013 terdapat banyak sekali perbedaan yang ditimbulkan dari kedua kurikulum, mulai dari segi perencanaannya, pelaksanaannya, pemahaman dan respon siswa serta penilaiaanya . Tujuan penelitian ini untuk mengetahui gambaran yang jelas mengenai: 1) persepsi guru terhadap penerapan KTSP dalam mata pelajaran Bahasa Indonesia, 2) persepsi guru terhadap penerapan Kurikulum 2013 dalam mata pelajaran Bahasa Indonesia, 3) perbedaan penerapan KTSP dan Kurikulum 2013 dalam mata pelajaran Bahasa Indonesia, 4) kurikulum yang paling efektif digunakan.

Penelitian ini merupakan penelitian lapangan yang memaparkan/menjelaskan kata demi kata secara deskriptif dengan menggunakan pendekatan kualitatif. Informan dalam penelitian ini yaitu guru kelas IV. Sumber data yang digunakan yaitu data primer dengan melakukan wawancara dengan guru kelas IV; dan sumber data sekunder diperoleh dari internet atau buku-buku. Data dianalisis dengan cara: pengumpulan data, reduksi data, penyajian data, dan penarikan kesimpulan.

Hasil penelitian menunjukkan bahwa persepsi guru terhadap penerapan KTSP dan Kurikulum 2013 dalam mata pelajaran Bahasa Indonesia berbeda-beda antara guru kelas IV A dan guru kelas IV B baik itu dari segi perencanaan, pelaksanaan, pemahaman dan respon siswa serta penilaiiannya seperti perencanaan yang menggunakan metode yang berbeda-beda dalam pelaksanaan mata pelajaran Bahasa Indonesia, pembelajaran Bahasa Indonesia yang diajarkan terpisah di KTSP dan menggunakan tema di Kurikulum 2013, penilaian KTSP yang menitik beratkan pada ranah kognitif membuat pemahaman anak mengenai pengetahuan lebih tinggi, sedangkan penilaian Kurikulum 2013 yang menitik beratkan pada ranah afektif yang menekankan pada karakter anak di sekolah. Perbedaan penerapan KTSP dan Kurikulum 2013 dalam mata pelajaran Bahasa Indonesia yang ditemukan berdasarkan hasil wawancara dituangkan dalam bentuk Tabel.4.5. Terdapat perbedaan persepsi guru mengenai kurikulum yang paling efektif digunakan sesuai dengan pengalaman belajar guru kelas IV masing-masing jika bagi guru tersebut kurikulum yang digunakan menyenangkan dalam proses pembelajaran dan dapat meningkat potensi siswa maka kurikulum tersebut yang paling efektif digunakan.
\end{abstract}

Kata kunci: Persepsi, KTSP, Kurikulum 2013, Bahasa Indonesia 
Abstract: This study is motivated by curriculum changes from KTSP to 2013 Curriculum giving different assumptions for each teacher who implements them because there are many differences in the KTSP and Curriculum from the two curricula, starting from the planning, implementation, understanding and response of students. and its assessment. The purpose of this study is to find a clear picture of: 1) teacher perceptions of the application of KTSP in Indonesian language subjects, 2) teacher perceptions of the application of 2013 curriculum in Indonesian language subjects, 3) differences in the application of 2013 KTSP and Curriculum in Indonesian subjects , 4) the most effective curriculum used.

This research is a field research which describes / explains word by word descriptively using a qualitative approach. The informants in this study were grade IV teachers. The data source used is primary data by conducting interviews with class IV teachers; and secondary data sources obtained from the internet or books. Data are analyzed by: data collection, data reduction, data presentation, and conclusion drawing.

The results showed that teachers' perceptions of the application of KTSP and Curriculum 2013 in Indonesian subjects differed between class IV A teachers and class IV B teachers both in terms of planning, implementation, understanding and response of students and their assessments such as planning using methods that different in the implementation of Indonesian language subjects, Indonesian language learning taught separately in KTSP and using themes in Curriculum 2013, KTSP assessment which focuses on the cognitive realm makes children's understanding of knowledge higher, while the 2013 Curriculum assessment which focuses on the realm affective which emphasizes the character of children in school. The differences in the application of KTSP and Curriculum 2013 in Indonesian language subjects found based on the results of the interviews are outlined in the form of Table.4.5. There are differences in teachers' perceptions of the most effective curriculum used in accordance with the learning experiences of each grade IV teacher if the teacher uses a fun curriculum in the learning process and can increase the potential of students, the curriculum is the most effective to use.

Keywords: Perception, KTSP, Curriculum 2013, Indonesian Lang

\section{PENDAHULUAN}

Ki Hajar Dewantara sebagai bapak pendidikan Indonesia, jauh-jauh waktu sebelum merdeka sudah mengisyaratkan pentingnya sebuah pendidikan. Menurutnya pendidikan merupakan kunci pembangunan bangsa. Pendidikan dilakukan melalui usaha untuk menuntun segenap kekuatan kodrat yang dimiliki anak, baik sebagai manusia maupun sebagai anggota masyarakat untuk mencapai keselamatan dan kebahagiaan setinggi-tingginya.

Para ahli meyakini bahwa daya saing suatu bangsa sangat bergantung pada penyelenggaraan pendidikannya yaitu pendidikan yang dapat mewujudkan sumber 
daya manusia bermutu. Mutu pendidikan yang dimaksud menyangkut dimensi proses dan hasil pendidikan. Mutu proses diukur dari indikator pencapaian skor prestasi lulusan baik menyangkut akademik maupun non akademik. (Arif. 2009)

Undang-undang Nomor 20 Tahun 2003 tentang Sistem Pendidikan Nasional menyebutkan, bahwa pendidikan nasional berfungsi mengembangkan kemampuan dan membentuk watak serta peradaban bangsa yang bermartabat dalam rangka mencerdaskan kehidupan bangsa. Pendidikan bertujuan untuk mengembangkan potensi peserta didik agar menjadi manusia yang beriman dan bertakwa kepada Tuhan Yang Maha Esa, berakhlak mulia, sehat, berilmu, cakap, kreatif, mandiri dan menjadi warga negara yang demokratis serta bertanggung jawab (Daryanto. 2014)

Di dalam ajaran agama Islam, pendidikan juga sangat penting dimana pendidikan itu di mulai dari proses baca dan tulis seperti yang dijelaskan di Q.S. AlAlaq ayat 1-5

Artinya :

1.Bacalah dengan (menyebut) nama Tuhanmu yang Menciptakan, 2. Dia telah menciptakan manusia dari segumpal darah. 3. Bacalah, dan Tuhanmulah yang Maha pemurah,4. Yang mengajar (manusia) dengan perantaran kalam, 5. Dia mengajar kepada manusia apa yang tidak diketahuinya. (Ahmad Tohaputra. 1998)

Pendidikan adalah salah satu bentuk perwujudan kebudayaan manusia yang dinamis dan sarat perkembangan. Oleh karena itu, perubahan atau perkembangan pendidikan adalah hal yang memang seharusnya terjadi sejalan dengan perubahan budaya kehidupan. Perubahan dalam arti perbaikan pendidikan pada semua tingkat perlu terus menerus dilakukan sebagai antisipasi kepentingan masa depan (Trianto. 2011)

Apabila kita ingin meningkatkan mutu pendidikan, tentunya tidak akan terlepas dari upaya peningkatan kualitas pembelajaran di sekolah. Menurut Komarudin dalam Trianto mengemukakan salah satu perubahan paradigma pembelajaran tersebut adalah orientasi pembelajaran yang semula berpusat pada guru (teacher centered) beralih berpusat pada murid (student centered), pendekatan yang semula lebih banyak bersifat tekstual berubah menjadi kontekstual. Semua perubahan tersebut dimaksudkan untuk memperbaiki mutu pendidikan, baik dari segi proses maupun hasil pendidikan. (Trianto.2011)

Pendidikan tidak terlepas dari kurikulum pendidikan yang diterapkan oleh pemerintah. Menurut Peraturan Pemerintah No.19 Tahun 2005 tentang Standar Nasional Pendidikan, kurikulum adalah seperangkat rencana dan pengaturan mengenai tujuan, isi dan bahan pelajaran serta cara yang digunakan sebagai pedoman penyelenggaraan kegiatan pembelajaran untuk mencapai tujuan pendidikan tertentu. (Daryanto.2013) 
Pada tahun ajaran baru 2013, Kurikulum 2013 telah diimplementasikan di seluruh Indonesia sebanyak 6329 sekolah sasaran yang terdiri atas 1027 SMK, 1267 SMA, 1437 SMP, dan 2598 SD yang tersebar di 34 Provinsi. (Endah 2014)

Salah satunya di provinsi Bengkulu yaitu SD Negeri 02 Centre Curup yang menerapkan Kurikulum 2013 sejak tahun ajaran 2013/2014 untuk kelas I, II, IV, dan V. Sedangkan untuk kelas III dan VI tetap menggunakan Kurikulum Tingkat Satuan Pendidikan (KTSP) tahun 2006. Merupakan hasil observasi tanggal 12 Desember 2014.

Kurikulum tematik atau Kurikulum 2013 dapat diartikan sebagai kurikulum yang memuat konsep pembelajaran terpadu yang menggunakan tema untuk mengaitkan beberapa mata pelajaran sehingga dapat memberikan pengalaman bermakna kepada para peserta didik dan semua mata pelajarannya diikat oleh kompetensi inti tiap kelasnya. Sedangkan KTSP tahun 2006 mata pelajaran lepas satu dengan yang lain, seperti sekumpulan mata pelajaran terpisah. Mata pelajaran Bahasa Indonesia di dalam Kurikulum 2013 diajarkan dengan menggunakan tema sedangkan di dalam KTSP tahun 2006 diajarkan secara tersendiri.

Akan tetapi kenyataannya, karena terdapat banyak perbedaan yang mencolok antara Kurikulum 2013 dengan KTSP, sehingga masih banyak sekolah, guru atau siswa yang belum mengetahui mengenai Kurikulum 2013 baik dari segi perencanaan, pelaksanaan serta penilaiannya. Bahkan ada juga guru yang telah mendapatkan pengetahuan mengenai Kurikulum 2013 namun mereka belum dapat mengimplementasikannya secara utuh dan masih terdapat kesulitan dalam proses pembelajaran di kelas dibandingkan dengan KTSP tahun 2006 .

Dengan persepsi individu dapat menyadari, dapat mengerti tentang keadaan lingkungan yang ada disekitarnya, dan juga tentang keadaan diri individu yang bersangkutan. Persepsi itu merupakan aktivitas yang integratif, maka seluruh yang ada dalam diri individu seperti perasaan, kemampuan berfikir, pengalamanpengalaman individu yang tidak sama, maka dalam mempersepsi suatu stimulus, hasil persepsi mungkin akan berbeda antara individu satu dengan individu lain. Keadaan tersebut memberikan gambaran bahwa persepsi itu memang bersifat individual. (Sarlito Wirawan Sarwono. 2013)

Maka dengan adanya stimulus yang sama mengenai Kurikulum 2013 dan KTSP 2006, pengalaman yang berbeda, pemikiran yang berbeda, tentunya masingmasing guru kelas IV yang mengajar mata pelajaran Bahasa Indonesia di SD Negeri 02 Centre Curup memiliki pengamatan serta persepsi sendiri dalam menilai Kurikulum 2013 dan KTSP 2006.

Berdasarkan hasil wawancara dengan kepala sekolah dan guru SD Negeri 02 Centre, masih terdapat guru yang memiliki persepsi dan pemahaman yang berbeda mengenai Kurikulum 2013 dan KTSP tahun 2006 dalam mata pelajaran Bahasa Indonesia, karena proses pembelajaran dan penilaiannya yang berbeda antara Kurikulum Tingkat Satuan Pendidikan (KTSP) dan Kurikulum 2013. Maka peneliti tertarik mengambil judul penelitian "Persepsi Guru terhadap Penerapan KTSP dan Kurikulum 2013 dalam Mata Pelajaran Bahasa Indonesia”. 


\section{Tujuan Penulisan}

Sejalan dengan rumusan masalah yang telah disusun, maka tujuan penelitian ini sebagai berikut:

1. Mengetahui gambaran yang jelas mengenai persepsi guru terhadap penerapan KTSP dalam mata pelajaran Bahasa Indonesia.

2. Mengetahui gambaran yang jelas mengenai persepsi guru terhadap penerapan Kurikulum 2013 dalam mata pelajaran Bahasa Indonesia.

3. Mengetahui gambaran yang jelas mengenai perbedaan penerapan KTSP dan Kurikulum 2013 dalam mata pelajaran Bahasa Indonesia.

4. Mengetahui gambaran yang jelas mengenai persepsi guru mengenai kurikulum yang lebih efektif digunakan di Sekolah Dasar.

\section{Manfaat Penulisan}

a. Dapat memberikan sumbangan ilmu pengetahuan khusus dalam kaitannya dengan penerapan Kurikulum 2013.

b. Dapat digunakan bagi para peneliti sebagai pertimbangan untuk mengadakan penelitian lebih lanjut mengenai Kurikulum 2013.

\section{Pengertian Persepsi}

Pengertian persepsi menurut Kamus Besar Bahasa Indonesia adalah "Persepsi adalah tanggapan (penerimaan langsung dari sesuatu) atau juga suatu proses seseorang mengetahui beberapa hal melalui panca indera, perhatian terhadap objek yang dipersepsi. (Suharso, dkk.2012)

Berdasarkan beberapa pendapat para ahli di atas maka penulis dapat memahami bahwa persepsi adalah tanggapan seseorang terhadap suatu objek dengan proses penginderaan yang di awali dengan proses penerimaan stimulus yang kemudian di proses di dalam otak yang akan menghasilkan sebuah pemahaman terhadap suatu objek yang di persepsi. Kembali kepada objek penelitian ini adalah Kurikulum Tingkat Satuan Pendidikan (KTSP) dan Kurikulum 2013 dalam mata pelajaran Bahasa Indonesia yang nantinya dihubungkan dengan persepsi guru terhadap pembelajaran tersebut. Tentu masing-masing individu memiliki pengamatan serta persepsi sendiri dalam menilai masing-masing kurikulum, persepsi yang mereka miliki akan berbeda antara individu satu dengan individu yang lain

\section{Faktor-faktor Yang Mempengaruhi Persepsi}

Berkaitan dengan faktor-faktor yang berperan dalam mempengaruhi persepsi Bimo Walgito mengemukakan adanya beberapa faktor yang mempengaruhi persepsi, yaitu:

1. Objek yang dipersepsi

Objek menimbulkan stimulus yang mengenai alat indera atau reseptor. Stimulus dapat datang dari luar individu yang mempersepsi, tetapi 
juga dapat datang dari dalam diri individu yang bersangkutan yang langsung mengenai syaraf penerima yang bekerja sebagai reseptor.

2. Alat indera, syaraf dan pusat susunan syaraf

Alat indera atau reseptor merupakan alat untuk menerima stimulus, disamping itu juga harus ada syaraf sensoris sebagai alat untuk meneruskan stimulus yang diterima reseptor ke pusat susunan syaraf, yaitu otak sebagai pusat kesadaran. sebagai alat untuk mengadakan respon diperlukan syaraf motorik.

3. Perhatian

Untuk menyadari atau untuk mengadakan persepsi diperlukan adanya perhatian yaitu merupakan langkah pertama sebagai suatu persiapan dalam rangka mengadakan persepsi. Perhatian merupakan pemusatan atau konsentrasi dari seluruh aktivitas individu yang ditujukan kepada sesuatu atau sekumpulan objek.

Dapat dipahami bahwa persepsi dapat dipengaruhi oleh perhatian seseorang terhadap suatu objeknya serta respon dari rangsangan yang diterima sehingga setiap individu memiliki persepsi yang berbeda-beda antara individu satu dengan individu yang lain.

\section{Pengertian Guru}

Menurut Undang-Undang Nomor 14 Tahun 2005 tentang Guru dan Dosen, bahwa baik guru maupun dosen merupakan pendidik profesional yang dituntut untuk melakukan perkerjaan secara profesional dalam rangka mencapai tujuan pendidikan sesuai dengan harapan. (Tanireja Tukiran dkk. 2010)

Berdasarkan beberapa pengertian diatas peneliti menganalisa bahwa guru merupakan tenaga pendidik profesional ditempuh melalui jalur pendidikan keguruan yang diperlukan dalam mengelola proses belajar mengajar, menjadi fasilitator bagi perserta didik serta mewujudkan tujuan pendidikan nasional.

\section{Tugas dan Peran Guru}

Menurut Ad. Rovijakkers dalam Suryosubroto mengemukakan tentang tugas mengajar guru meliputi mengurutkan bahan, memilih masalah pokok dan tambahan, memilih alat peraga, cara menyajikan bahan dan mengukur kemampuan murid.

Menurut Rusman dalam bukunya, peran guru berkaitan dengan kompetensi guru, diantaranya sebagai berikut:

1. Guru melakukan diagnosis terhadap perilaku awal siswa

Guru harus mampu membantu kesulitan-kesulitan yang dihadapi siswanya dalam proses pembelajaran. proses assessing atau memperkirakan keadaan siswa adalah langkah awal untuk mengetahui lebih lanjut kondisi siswa untuk kemudian dievaluasi agar lebih konkret dan mendekati tepat untuk memahami keadaan siswanya, sehingga 
diharapkan jika guru telah mengetahui betul kondisi siswanya akan mempermudah memberikan materi pelajaran yang sesuai dengan minat dan bakat siswa.

2. Guru membuat Rencana Pelaksanaan Pembelajaran (RPP).

Perencanaan pembelajaran adalah membuat persiapan pembelajaran. guru diharapkan dapat melakukan persiapan pembelajaran baik menyangkut materi pembelajaran maupun kondisi psikis dan psikologis yang kondusif bagi berlangsungnya proses pembelajaran.

3. Guru melaksanakan proses pembelajaran

Proses interaksi pembelajaran terjadi di dalam kelas. Ada beberapa hal yang harus diperhatikan guru: 1) mengatur waktu berkenaan dengan berlangsungnya proses pembelajaran, 2) memberikan dorongan kepada siswa, 3) melaksanakan diskusi dalam kelas, 4) mengamati siswa dalam berbagai kegiatan, 4) menggunakan alat peraga.

4. Guru sebagai evaluator

Setiap kali proses belajar mengajar, guru hendaknya menjadi evaluator yang baik. Penilaian dilakukan untuk mengetahui apakah tujuan yang telah dirumuskan itu tercapai atau tidak, apakah materi yang diajarkan sudah dikuasai tau belum oleh siswa dan apakah metode yang digunakan sudah cukup tepat. ( Suyadi, 2013)

Berdasarkan beberapa pendapat para ahli di atas penulis menganalisa bahwa tugas dan peran guru adalah mengadakan persiapan pembelajaran, mempelajari terlebih dahulu materi yang akan diajarkan kepada peserta didik serta mempersiapkan alat-alat yang dibutuhkan dalam proses pembelajaran, sedangkan peran guru adalah sebagai sumber belajar yang bagi peserta didik serta, sebagai pengelola pembelajaran dimana bertugas untuk mengawasi dan memimpin proses pembelajaran dan sebagai penilai hasil pembelajaran

\section{Kurikulum Tingkat Satuan Pendidikan (KTSP) dan Kurikulum 2013 Pengertian Kurikulum}

Menurut Sudirman dan Tabrani Rusyan dalam Trianto menjelaskan bahwa kurikulum (curriculum), secara etimologis berasal dari bahasa Yunani yaitu curir yang artinya "pelari" dan curere yang berarti "tempat berpacu". Jadi, istilah kurikulum berasal dari dunia olahraga pada zaman Romawi kuno di Yunani yang mengandung pengertian suatu jarak yang harus ditempuh oleh pelari dari garis start sampai garis finish. Secara etimologis istilah kurikulum digunakan dalam dunia pendidikan dengan pengertian semula ialah sejumlah pengetahuan atau mata pelajaran yang harus ditempuh atau diselesaikan siswa guna mencapai suatu tingkatan atau ijazah. (Trianto. 2011) 
Menurut Undang-undang Sistem Pendidikan Nasional Nomor 20 tahun 2003 dalam Hendra Harmi menyatakan kurikulum adalah seperangkat rencana dan pengaturan mengenai tujuan, isi dan bahan pelajaran serta cara yang digunakan sebagai pedoman penyelanggaraan kegiatan pembelajaran untuk mencapai tujuan pendidikan tertentu. (Hendra Harmi, 2010)

Beberapa pendapat, dapat pahami bahwa kurikulum adalah segala pengetahuan mata pelajaran yang harus ditempuh dan dikuasai oleh peserta didik untuk mencapai suatu tingkatan atau ijazah yang berada pada bimbingan atau tanggung jawab sekolah.

\section{Kurikulum Tingkat Satuan Pendidikan (KTSP)}

Menurut Lukmanul Hakim dalam bukunya Kurikulum Tingkat Satuan Pendidikan (KTSP) adalah kurikulum operasional yang disusun oleh dan dilaksanakan di masing-masing satuan pendidikan. KTSP terdiri dari tujuan tingkat satuan pendidikan, struktur dan muatan kurikulum tingkat satuan pendidikan, kalender pendidikan dan silabus. (Lukmanul Hakim, 2012)

Menurut Permen No. 19 tahun 2005 tentang Standar Nasional Pendidikan dalam Hendra, Pengembangan Kurikulum Tingkat Satuan Pendidikan (KTSP) yang beragam mengacu pada Standar Nasional Pendidikan untuk menjamin pencapaian tujuan pendidikan nasional. Standar Nasional Pendidikan terdiri atas standar isi, standar proses, kompetensi lulusan, tenaga kependidikan, sarana dan prasarana pengelolaan, pembiayaan dan penilaian pendidikan.

Menurut Permendiknas No. 22 tahun 2006 dalam Hendra, Standar isi mencakup kerangka dasar dan struktur kurikulum, Standar Kompetensi (SK) dan Kompetensi Dasar (KD) setiap mata pelajaran pada setiap semester dari setiap jenis dan jenjang pendidikan dasar dan menengah. Menurut Permendiknas No. 22 tahun 2006 dalam Hendra, Standar kelulusan adalah kualifikasi kemampuan lulusan mencakup sikap, pengetahuan dan keterampilan. Berdasarkan pernyataan diatas dapat dipahami:

1. Standar Isi merupakan rumusan Standar Kompetensi dan Kompetensi Dasar untuk semua mata pelajaran telah disusun secara nasional oleh Badan Standar Nasional Pendidikan (BSNP). Pengembangannya dapat dilakukan oleh sekolah dengan memperhatikan rumusan SK-KD yang telah disusun oleh BSNP.

2. SK-KD di atas menjadi pedoman bagi guru dalam menyusun rencana pembelajaran berupa Silabus dan Rencana Pelaksanaan Pembelajaran (RPP). 


\section{Kurikulum 2013}

Acuan prinsip penyusunan kurikulum 2013 mengacu pada pasal 36 Undang-Undang No. 20 tahun 2003, yang menyatakan bahwa penyusunan kurikulum harus memperhatikan peningkatan iman dan takwa, peningkatan akhlak mulia, peningkatan potensi, kecerdasan, dan minat peserta didik, keragaman potensi daerah dan lingkungan, tuntutan pembangunan daerah dan nasional, tuntutan dunia kerja, perkembangan ilmu pengetahuan, teknologi dan seni, agama dinamika, perkembangan global dan persatuan nasional dan kebangsaan.

Tujuan pembelajaran disesuaikan dengan tujuan pendidikan nasional yang dinyatakan pada pasal 3 UU No. 20 tahun 2003, yakni "berkembangnya potensi peserta didik agar menjadi manusia yang beriman dan bertakwa kepada Tuhan Yang Maha Esa, berakhlak mulia, sehat, berilmu, cakap, kreatif, mandiri, dan menjadi warga negara yang demokratis serta bertanggung jawab". Berlandaskan pada landasan yuridis tersebut, dapat dikategorikan hasil belajar yang harus dicapai oleh siswa dalam kurikulum 2013, yaitu sebagai berikut :

1. Sikap spiritual mecakup beriman dan bertakwa kepada Tuhan Yang Maha Esa.

2. Sikap sosial mencakup berakhlak mulia, sehat, mandiri, dan demokratis serta bertanggung jawab.

3. Pengetahuan atau berilmu.

4. Keterampilan yang cakap dan kreatif. (Ridwan Abdullah Sani. 2014)

Tabel 2.1

Kemampuan yang harus dimiliki oleh lulusan Sekolah Dasar

\begin{tabular}{|l|l|}
\hline \multicolumn{1}{|c|}{ Dimensi } & \multicolumn{1}{c|}{ Kualifikasi Kemampuan } \\
\hline Sikap & $\begin{array}{l}\text { Memiliki perilaku yang mencerminkan sikap orang beriman, } \\
\text { berakhlak mulia, berilmu, percaya diri, dan bertanggung jawab } \\
\text { dalam berinteraksi secara efektif dengan lingkungan sosial dan } \\
\text { alam di lingkungan rumah, sekolah, dan tempat bermain }\end{array}$ \\
\hline Pengetahuan & $\begin{array}{l}\text { Memiliki pengetahuan faktual dan konseptual berdasarkan rasa } \\
\text { ingin tahunya tentang ilmu pengetahuan, teknologi, seni dan } \\
\text { budayadalam wawasan kemanusiaan, kebangsaan, kenegaraan, } \\
\text { dan peradaban terkait fenomena dan kejadian di lingkungan } \\
\text { rumah, sekolah dan dan tempat bermain. }\end{array}$ \\
\hline
\end{tabular}




\begin{tabular}{|l|l|}
\hline Keterampilan & $\begin{array}{l}\text { Memiliki kemampuan pikir dan tindak yang produktif dan kreatif } \\
\text { dalam ranah abstrak dan konkret sesuai dengan yang ditugaskan } \\
\text { kepadanya }\end{array}$ \\
\hline
\end{tabular}

Berikut adalah komponen yang yang dituangkan dalam UU No.20 tahun 2003, pasal 3 (Ridwan Abdullah Sani.2014)

Tabel 2.2

Komponen Hasil Belajar Kurikulum 2013

\begin{tabular}{|l|l|c|}
\hline \multicolumn{1}{|c|}{ Dimensi } & \multicolumn{1}{c|}{ Deskripsi } & Kompetensi \\
\hline $\begin{array}{l}\text { Sikap } \\
\text { Spritual }\end{array}$ & $\begin{array}{l}\text { beriman dan bertakwa kepada Tuhan } \\
\text { Yang Maha Esa }\end{array}$ & Kompetensi Inti 1(KI 1) \\
\hline Sikap Sosial & $\begin{array}{l}\text { Berakhlak mulia, sehat, mandiri, dan } \\
\text { demokratis serta bertanggung jawab }\end{array}$ & $\begin{array}{c}\text { Kompetensi Inti 2 } \\
\text { (KI 2) }\end{array}$ \\
\hline Pengetahuan & Berilmu & Kompetensi Inti 3(KI 3) \\
\hline Keterampilan & Cakap dan Kreatif & Kompetensi Inti 4(KI 4) \\
\hline
\end{tabular}

\section{Elemen Perubahan Kurikulum.}

Kesenjangan kurikulum dapat dilihat dari 6 aspek yaitu: a) kompetensi lulusan, b) materi pembelajaran, c) proses pembelajaran, d) penilaian, e) pendidik dan tenaga kependidikan dan f) pengelolaan kurikulum (Abdul Majid. 2013)

Tabel 2.3

\section{Kesenjangan Kurikulum}

\begin{tabular}{|c|c|c|c|}
\hline NO & ASPEK & KONDISI SAAT INI & KONDISI IDEAL \\
\hline 1 & $\begin{array}{l}\text { Kompetensi } \\
\text { Lulusan }\end{array}$ & $\begin{array}{ll} & \text { Belum sepenuhnya } \\
\text { menekankan pendidikan } \\
\text { karakter } \\
\text { - } & \text { Belum menghasilkan } \\
\text { keterampilan sesuai } \\
\text { kebutuhan } \\
\text { - } & \text { Pengetahuan-pengetahuan } \\
\text { lepas }\end{array}$ & $\begin{array}{ll}- & \text { Berkarakter mulia } \\
\text { - } & \text { Keterampilan yang } \\
& \text { relevan } \\
- & \text { Pengetahuan- } \\
& \text { pengetahuan terkait }\end{array}$ \\
\hline
\end{tabular}




\begin{tabular}{|c|c|c|c|}
\hline 2 & $\begin{array}{l}\text { Materi } \\
\text { Pembelajaran }\end{array}$ & $\begin{array}{ll}\text { - } & \text { Belum relevan dengan } \\
\text { kompetensi yang } \\
\text { dibutuhkan } \\
\text { - } \quad \begin{array}{l}\text { Beban belajar terlalu berat } \\
\text { - }\end{array} \\
\begin{array}{l}\text { Terlalu keras kurang } \\
\text { mendalam }\end{array}\end{array}$ & $\begin{array}{ll}\text { - } & \text { Relevan dengan } \\
& \text { kompetensi yang } \\
\text { dibutuhkan } \\
\text { - } & \text { Materi esensial } \\
\text { - } & \text { Sesua dengan tingkat } \\
& \text { perkembangan anak }\end{array}$ \\
\hline 3 & $\begin{array}{l}\text { Proses } \\
\text { Pembelajaran }\end{array}$ & $\begin{array}{ll}- & \text { Berpusat pada guru } \\
\text { - } & \text { Sifat pembelajaran yang } \\
& \text { berorientasi pada buku teks } \\
\text { - } & \text { Buku teks hanya memuat } \\
& \text { materi bahasan }\end{array}$ & $\begin{array}{ll}\text { - } & \text { Berpusat pada } \\
\text { peserta didik } \\
\text { - } & \text { Sifat pembelajaran } \\
\text { yang kontekstual } \\
\text { - } & \text { Bukuteks memuat } \\
\text { materi dan proses } \\
\text { pembelajaran, sistem } \\
\text { penilaian serta } \\
\text { kompetensi yang } \\
\text { diharapkan }\end{array}$ \\
\hline 4 & Penilaian & $\begin{array}{ll}- & \text { Menekankan aspek kognitif } \\
\text { - } & \text { Test menjadi cara penilaian } \\
& \text { yang dominan }\end{array}$ & $\begin{array}{ll}\text { - } & \text { Menekankan aspek } \\
\text { kognitif, afektif, } \\
\text { psikomotorik secara } \\
\text { proporsional } \\
\text { - } \\
\text { Penilaian test dan } \\
\text { portofolio saling } \\
\text { melengkapi } \\
\end{array}$ \\
\hline 5 & $\begin{array}{l}\text { Pendidik dan } \\
\text { Tenaga } \\
\text { Kependidika } \\
\mathrm{n}\end{array}$ & $\begin{array}{ll}\text { - } & \text { Memenuhi kompetensi } \\
\text { profesi saja } \\
\text { - } & \text { Fokus pada ukuran kinerja } \\
& \text { PTK }\end{array}$ & $\begin{array}{ll}\text { - } & \text { Memenuhi } \\
\text { kompetensi profesi, } \\
\text { pedagogi, sosial, dan } \\
\text { personal } \\
\text { - } \quad \text { Motivasi mengajar } \\
\end{array}$ \\
\hline 6 & $\begin{array}{l}\text { Pengelolaan } \\
\text { Kurikulum }\end{array}$ & $\begin{array}{ll}\text { - } & \text { Satuan pendidikan } \\
\text { mempunyai kebebasan } \\
\text { dalam pengelolaan } \\
\text { kurikulum } \\
\text { - } \\
\text { Penyusunan kurikulum } \\
\text { terkadang tidak } \\
\text { memperhatikan kondisi } \\
\text { satuan pendidikan, } \\
\text { kebutuhan peserta didik dan } \\
\text { potensi daerah } \\
\text { - Pemerintah hanya } \\
\text { menyediakan sampai } \\
\text { standar isi mata pelajaran }\end{array}$ & 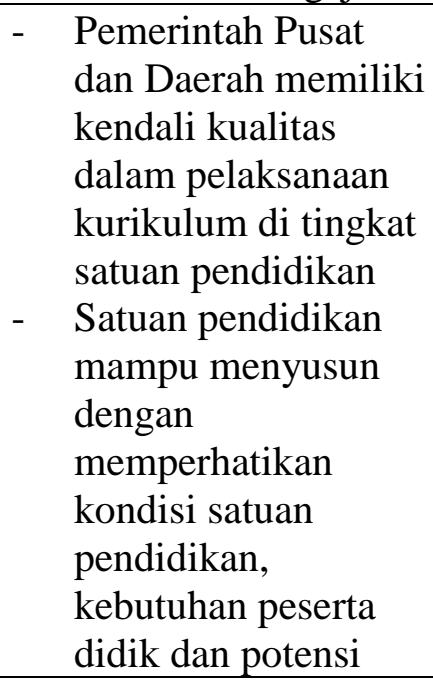 \\
\hline
\end{tabular}




\begin{tabular}{|l|l|l|}
\hline & & daerah \\
& & - \\
& & Pemerintah \\
& menyiapkan semua \\
& komponen kurikulum \\
& sampai buku teks dan \\
& & pedoman \\
\hline
\end{tabular}

\section{Elemen Perubahan Kurikulum}

Elemen perubahan kurikulum di Sekolah Dasar (SD) dilakukan pada empat komponen, yaitu: a) Standar Kompetensi Lulusan, b) Standar Isi, c) Standar Proses, dan d) Standar Penilaian. Untuk lebih jelasnya dapat dilihat dalam tabel 2.4, (Abdul Majid. 2013)

\section{Tabel 2.4}

Elemen Perubahan Kurikulum dalam Standar Kompetensi Lulusan (SKL)

\begin{tabular}{|c|l|}
\hline Elemen & \multicolumn{1}{|c|}{ Sekolah Dasar } \\
\hline Kompetensi Lulusan & $\begin{array}{l}\text { Adanya peningkatan dan keseimbangan soft skills } \\
\text { dan hard skills yang meliputi aspek kompetensi } \\
\text { sikap, keterampilan dan pengetahuan. }\end{array}$ \\
\hline $\begin{array}{c}\text { Kedudukan Mata Pelajaran } \\
\text { (ISI) }\end{array}$ & $\begin{array}{l}\text { Kompetensi yang semula diturunkan dari mata } \\
\text { pelajaran berubah menjadi mata pelajaran yang } \\
\text { dikembangkan dari kompetensi }\end{array}$ \\
\hline (ISI) & Tematik integratif dalam semua mata pelajaran. \\
\hline
\end{tabular}

Tabel 2.5

Elemen Perubahan Kurikulum dalam Standar Isi

\begin{tabular}{|c|c|}
\hline Elemen & Sekolah Dasar \\
\hline $\begin{array}{c}\text { Struktur Kurikulum (Mata pelajaran dan } \\
\text { alokasi waktu) (ISI) }\end{array}$ & $\begin{array}{ll}\text { - } & \text { Holistik dan integratif berfokus } \\
\text { kepada alam, sosial dan budaya } \\
\text { - } & \text { Pembelajaran dilaksanakan } \\
\text { dengan pendekatan sains } \\
\text { - } \quad \text { Jam mata pelajaran dari } 10 \\
\text { menjadi } 6 \\
\text { - } & \text { Jumlah jam bertambah } 4 \\
& \text { JP/minggu akibat perubahan }\end{array}$ \\
\hline
\end{tabular}


Tabel 2.6

Elemen Perubahan Kurikulum dalam Standar Proses

\begin{tabular}{|l|l|}
\hline Elemen & \multicolumn{1}{|c|}{ Sekolah Dasar } \\
\hline \multirow{2}{*}{ Proses Pembelajaran } & $\begin{array}{l}\text { Standar proses yang semula terfokus } \\
\text { pada eksplorasi, elaborasi dan } \\
\text { konfirmasi dilengkapi dengan } \\
\text { mengamati, menanya, mengolah, } \\
\text { menalar, menyajikan, menyimpulkan } \\
\text { dan mencipta }\end{array}$ \\
\cline { 2 - 2 } & $\begin{array}{l}\text { Belajar tidak hanya terjadi di ruang } \\
\text { kelas, tetapi juga di lingkungan } \\
\text { sekolah dan masyarakat }\end{array}$ \\
\cline { 2 - 2 } & $\begin{array}{l}\text { Guru bukan satu-satunya sumber } \\
\text { belajar }\end{array}$ \\
\cline { 2 - 2 } & $\begin{array}{l}\text { Sikap tidak diajarkan secara verbal } \\
\text { melainkan dengan contoh dan teladan }\end{array}$ \\
\cline { 2 - 2 } & Tematik dan terpadu \\
\hline
\end{tabular}

Tabel 2.7

Elemen Perubahan Kurikulum dalam Standar Penilaian

\begin{tabular}{|l|l|}
\hline Elemen & \multicolumn{1}{|c|}{ Sekolah Dasar } \\
\hline \multirow{5}{*}{ Penilaian } & Penilaian berbasis kompetensi \\
\cline { 2 - 2 } & $\begin{array}{l}\text { Pergeserandari penilaian melalui tes (mengukur } \\
\text { kompetensi pengetahuan berdasarkan hasil saja), } \\
\text { menuju penilaian otentik (mengukur semua } \\
\text { kompetensi sikap, keterampilan dan pengetahuan } \\
\text { berdasarkan proses dan hasil) }\end{array}$ \\
\cline { 2 - 2 } & $\begin{array}{l}\text { Merperkuat PAP (Penilaian Acuan Patokan), yaitu } \\
\text { pencapaian hasil belajar didasarkan pada skor yang } \\
\text { diperolehnya terhadap skor ideal (maksimal) }\end{array}$ \\
\hline
\end{tabular}


Penilaian tidak hanya pada level KD, tetapi juga kompetensi inti dan SKL

Mendorong pemanfaatan portofolio yang dibuat siswa sebagai instrumen utama penilaian

\section{Mata Pelajaran Bahasa Indonesia}

Menurut Ngalimun, bahasa merupakan satu wujud yang tidak terpisahkan dari kehidupan manusia, sehingga dapat dikatakan bahwa bahasa merupakan milik manusia yang telah menyatu dengan pemiliknya sebagai salah satu milik manusia, bahasa selalu muncul dalam berbagai aspek kegiatan manusia. Bahasa merupakan alat untuk berinteraksi. (Ngalimun dan Noor Alfulaila.2014)

Bahasa memiliki peran sentral dalam perkembangan intelektual, sosial, dan emosional peserta didik dan merupakan penunjang keberhasilan dalam mempelajari semua bidang studi. Pembelajaran bahasa diharapkan membantu peserta didik mengenal dirinya, budayanya, dan budaya orang lain, mengemukakan gagasan dan perasaan, berpartisipasi dalam masyarakat yang menggunakan bahasa tersebut, dan menemukan serta menggunakan kemampuan analisis dan imaginatif yang ada dalam dirinya.

\section{Aspek-aspek Keterampilan Berbahasa}

Terdapat empat keterampilan dasar berbahasa yaitu mendengarkan (menyimak), berbicara, membaca dan menulis. Mendengarkan adalah keterampilan memahami bahasa lisan yang bersifat reseptif. Dengan demikian, mendengarkan disini berarti bukan sekadar mendengarkan bunyi-bunyi bahasa melainkan sekaligus memahaminya. (Yeti Mulyati dkk, 2009)

Bahwa Bahasa Indonesia memiliki empat keterampilan berbahasa yaitu membaca, menyimak atau mendengarkan, menulis dan berbicara dan keempat keterampilan berbahasa tersebut saling berhubungan erat antara satu dengan yang lain.

\section{Fungsi Bahasa Indonesia}

Bahasa Indonesia memiliki fungsi khusus sesuai dengan kedudukannya sebagai bahasa negara (Undang-Undang Dasar 1945 Bab XV Pasal 36) yaitu sebagai bahasa resmi negara., sebagai bahasa pengantar dalam dunia pendidikan, sebagai alat penghubung pada tingkat nasional untuk kepentingan perencanaan dan pembangunan nasional serta kepentingan pemerintah, sebagai alat pengembangan kebudayaan, ilmu pengetahuan dan teknologi.(Yusi Rosdiana,2011)

Menurut Yusi Rosdiana dalam bukunya, Bahasa Indonesia mempunyai kedudukan sebagai bahasa nasional sejak dicetuskan Sumpah Pemuda pada 
tanggal 28 Oktober 1928. Sesuai dengan kedudukannya sebagai bahasa nasional, bahasa Indonesia berfungsi sebagai:

1. Lambang kebanggaan kebangsaan.

2. Lambang identitas nasional.

3. Alat yang memungkinkan penyatuan berbagai suku bangsa dengan latar belakang sosial budaya dan bahasa masing-masing kedalam kesatuan kebangsaan Indonesia.

4. Alat penghubung antardaerah dan antarbudaya. (Yusi Rosdiana,2011)

Menurut Abdul Chaer dalam bukunya, Bahasa Indonesia merupakan alat untuk bekerja sama atau berkomunikasi di dalam skehidupan manusia bermasyarakat, serta dapat juga berfungsi sebagai berikut :

1. Alat untuk menjalankan adsministrasi negara

2. Alat pemersatuberbagai suku bangsa di Indonesia.

3. Media untuk menampung kebudayaan nasional. (Abdul Chaer.2000)

Berdasarkan beberapa pendapat para ahli di atas bahwa fungsi Bahasa Indonesia adalah sebagai alat pemersatu bangsa, karena bangsa Indonesia terdiri dari bermacam-macam suku bangsa dengan latar belakang sosial yang berbedabeda, sehingga bahasa daerah yang digunakan juga cukup banyak maka Bahasa Indonesia yang digunakan untuk berkomunikasi.

\section{Pendekatan dalam Penelitian}

Menurut Nana Syaodih dalam bukunya penelitian kualitatif ditujukan untuk memahami fenomena-fenomena sosial dari sudut atau pandangan partisipan. Partisipan adalah orang-orang yang diajak wawancara, diobservasi, diminta memberikan data, pendapat, pemikiran dan persepsinya. (Nana Syaodih Sukmadinata. 2010)

Pendekatan yang digunakan dalam penelitian ini adalah menggunakan deskriptif kualitatif yang bertujuan untuk menafsirkan dan menyajikan data yang bersangkutan dengan situasi yang sedang terjadi, sikap serta pandangan yang terjadi di dalam masyarakat, pertentangan keadaan, hubungan antarvariabel, perbedaan antar fakta dan lain-lain.

\section{Jenis dan Sumber Data}

Jenis data diperoleh dari data primer dan data sekunder. Data primer adalah data yang diperoleh atau dikumpulkan oleh peneliti secara langsung dari sumber datanya. Untuk mendapatkan data primer, peneliti harus mengumpulkannya secara langsung. Data diperoleh dari hasil wawancara.

Data Sekunder adalah data yang diperoleh atau dikumpulkan peneliti dari berbagai sumber yang telah ada (peneliti sebagai tangan kedua). Membaca bukubuku atau jurnal. 
Menurut Suharsimi Arikunto yang dimaksud dengan sumber data dalam penelitian subjek dari mana data dapat diperoleh. Adapun sumber data yang diperoleh dari penelitian ini adalah :

1. Di SDN 02 Centre Curup.

2. Studi kepustakaan, artikel, internet dll

\section{Teknik Analisis Data}

Teknik analisis data yang digunakan dalam penelitian ini adalah model Miles and Huberman. Miles dan Huberman mengemukakan bahwa aktifitas dalam analisis data kualitatif dilakukan secara interaktif dan berlangsung secara terus menerus sampai tuntas, sehingga datanya sudah jenuh. Aktifitas dalam aalisis data, yaitu data reduction, data display dan conclusion drawing/verification. (Sugiyono. 2011)

Data dari hasil dokumentasi adalah merupakan bukti otentik yang menjelaskan bahwa peneliti benar-benar melakukan penelitian di SD Negeri 02 Centre Curup, data dokumentasi berupa foto-foto ketika mewawancarai guru, data sekolah dan data para guru yang mengajar disana.

Tabel 3.1.

Kisi-kisi Instrumen Penelitian

\begin{tabular}{|c|c|c|c|c|}
\hline $\begin{array}{l}\text { Variabel } \\
\text { Penelitian }\end{array}$ & $\begin{array}{c}\text { Sumber } \\
\text { Data }\end{array}$ & Metode & Instrumen & $\begin{array}{c}\text { No. } \\
\text { Pertanyaan }\end{array}$ \\
\hline $\begin{array}{l}\text { Persepsi guru } \\
\text { terhadap } \\
\text { Penerapan KTSP } \\
\text { dalam mata } \\
\text { pelajaran Bahasa } \\
\text { Indonesia }\end{array}$ & 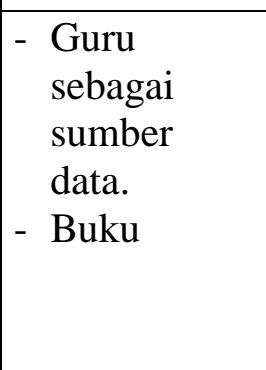 & $\begin{array}{l}\text { Wawancara } \\
\text { terpimpin }\end{array}$ & $\begin{array}{l}\text { Pedoman } \\
\text { wawancara }\end{array}$ & $\begin{array}{l}1 \\
2 \\
3 \\
4 \\
9\end{array}$ \\
\hline $\begin{array}{l}\text { Persepsi guru } \\
\text { terhadap } \\
\text { Penerapan } \\
\text { Kurikulum } 2013 \\
\text { dalam mata } \\
\text { pelajaran Bahasa } \\
\text { Indonesia }\end{array}$ & \begin{tabular}{|l} 
- Guru \\
sebagai \\
sumber data \\
- Buku
\end{tabular} & $\begin{array}{l}\text { Wawancara } \\
\text { terpimpin }\end{array}$ & $\begin{array}{l}\text { Pedoman } \\
\text { wawancara }\end{array}$ & $\begin{array}{l}5 \\
6 \\
7 \\
8 \\
9\end{array}$ \\
\hline
\end{tabular}




\section{Deskripsi Temuan Khusus Penelitian}

Berdasarkan hasil wawancara penelitian terhadap guru SD Negeri 02 Centre Curup Kelas IV mengenai bagaimana gambaran persepsi guru SD Negeri 02 Centre Curup yang sudah mendapatkan pengalaman mengajar menggunakan KTSP dan Kurikulum 2013 terhadap mata pelajaran Bahasa Indonesia. Ternyata terdapat perbedaan persepsi diantara kedua guru kelas IV yaitu guru kelas IV A dan guru kelas IV B mengenai penerapan KTSP dan Kurikulum 2013 terhadap mata pelajaran Bahasa Indonesia. Adapun hasil wawancara dengan guru kelas IV A dan guru kelas IV B.

\section{Persepsi Guru Mengenai Kurikulum Yang Lebih Efektif Digunakan Di SD Negeri 02 Centre Curup.}

Kurikulum merupakan program pendidikan yang disediakan oleh lembaga pendidikan (sekolah) bagi siswa. Berdasarkan program pendidikan tersebut siswa melakukan berbagai kegiatan belajar, sehingga mendorong perkembangan dan pertumbuhannya yang sesuai dengan tujuan pendidikan yang ditetapkan.

Perubahan kurikulum yang terjadi sebagai salah satu langkah pemerintah untuk meningkatkan mutu pendidikan di Indonesia. Perubahan kurikulum yang terjadi dari Kurikulum Tingkat Satuan Pendidikan (KTSP) tahun 2006 menjadi Kurikulum 2013 memunculkan berbagai persepsi mengenai kedua kurikulum tersebut.

Di SD Negeri 02 Centre Curup, Kurikulum Tingkat Satuan Pendidikan (KTSP) 2006 dan Kurikulum 2013 diterapkan secara bersama-sama sejak tahun ajaran 2013/2014. KTSP 2006 diterapkan di kelas III dan VI, sedangkan Kurikulum 2013 diterapkan di kelas I, II, IV dan V. (Observasi 4 Mei 2015)

Berdasarkan hasil wawancara yang dikemukan oleh guru kelas VI A ibu Dewi Sri Budi mengenai kurikulum yang paling efektif diterapkan di SD Negeri 02 Curup, beliau mengemukakan bahwa:

"Kurikulum yang lebih efektif digunakan adalah Kurikulum 2013 karena anak menemukan sendiri dalam proses pembelajaran tetapi pemerintah tetap harus memperhatikan sarana dan prasarananya seperti buku pegangan guru dan buku pegangan siswa."(Dewi Sri Budi, Wawancara,Tanggal 4 April 2015)

Berbeda dengan yang dikemukakan oleh guru kelas VI B bapak Sugih Riang, beliau berpendapat bahwa Kurikulum Tingkat Satuan Pendidikan (KTSP) 2006 yang lebih efektif digunakan di SD Negeri 02 Centre Curup jika yang dititik beratkan adalah ranah kognitif siswanya. Berikut adalah hasil wawancara dengan bapak Sugih Riang, beliau mengemukakan bahwa:

"Tergantung dengan ranah yang diinginkan, jika ranah afektif Kurikulum 2013 yang lebih tepat digunakan, tetapi jika ranah kognitif KTSP yang lebih tepat digunakan. KTSP adalah kurikulum yang paling tepat 
digunakan karena pengetahuan diajarkan lebih mendalam sehingga pengetahuan siswa tinggi. Tetapi guru yang lebih banyak aktif."(Sugih Riang, Wawancara,Tanggal 16 April 2015)

Berdasarkan hasil wawancara dengan 2 orang guru kelas IV yaitu kelas IV A dan guru kelas IV B SD Negeri 02 Centre Curup dapat dipahami bahwa terjadi perbedaan persepsi antara mereka mengenai kurikulum yang lebih efektif digunakan di SD Negeri 02 Centre Curup. Guru kelas IV A ibu Dewi Sri Budi S.Pd mengatakan bahwa Kurikulum 2013 yang paling efektif digunakan di sekolah, karena pembelajarannya yang menyenangkan dan menekankan pada karakter siswa. Berbeda dengan tanggapan yang diberikan guru kelas IV B bapak Sugih Riang S.Pd beliau mengatakan bahwa KTSP 2006 yang palig efektif digunakan karena menekankan pada kognitif siswa, pembelajaran materi yang lebih mendalam serta penilaian yang tidak sulit dilakukan oleh guru.

dapat disimpulkan, keefektifan suatu kurikulum hanya bisa dirasakan oleh pengalaman-pengalaman guru dalam hal mengajar baik itu menggunakan KTSP 2006 maupun Kurikulum 20013. Jika guru tersebut beranggapan mengajar menggunakan KTSP itu sangat menyenangkan dan menarik perhatian siswa, maka kurikulum KTSP yang paling efektif digunakan. Tetapi jika guru beranggapan bahwa menggajar menggunakan Kurikulum 2013 lebih menyenangkan dan membuat siswa lebih aktif dalam proses pembelajaran maka Kurikulum 2013 yang paling efektif digunakan.

\section{Pembahasan Hasil Penelitian}

Dari hasil penelitian dapat disimpulkan secara umum bahwa penerapan KTSP dan Kurikulum 2013 dalam mata pelajaran Bahasa Indonesia memiliki banyak perbedaan didalam menerapkannya di kelas IV SD Negeri 02 Centre Curup baik itu dari segi persiapan guru, pelaksanaannya, pemahaman dan respon siswa serta hasil belajar siswa. Guru kelas IV juga berbeda persepsi mengenai kurikulum yang lebih efektif digunakan di SD Negeri 02 Centre, keefektifan suatu kurikulum hanya bisa dirasakan oleh guru yang memiliki pengalaman mengajar menggunakan KTSP 2006 dan Kurikulum 2013.

\section{Simpulan}

1. Persepsi guru kelas IV A dan guru kelas IV B mengenai mata pelajaran dalam KTSP 2006 adalah baik, karena KTSP pembelajaran yang menggunakan pemisahan mata pelajaran sehingga tampak antara mata pelajaran satu dengan yang lainnya, selain itu penilaian yang bersifat kuantitatif atau angka membuat siswa puas dengan hasil belajar akhir yang mereka dapat. Serta penitik beratan pada ranah kognitif membuat siswa memiliki pengetahuan yang lebih tinggi.

2. Persepsi guru kelas IV A mengenai mata pelajaran Bahasa Indonesia dalam Kurikulum 2013 adalah sangat baik, menurutnya pembelajaran yang 
ditawarkan Kurikulum 2013 adalah pembelajaran yang menyenangkan sehingga membuat pemahaman siswa menjadi meningkat dibanding dengan KTSP 2006, siswa dilatih untuk bisa berbicara di depan kelasnya masingmasing, hanya saja penilaian dalam Kurikulum 2013 terlalu sulit karena harus setiap hari mengobservasi siswa menggunakan rubrik penilaian 3 ranah yaitu afektif, kognitif dan psikomotorik. Persepsi yang sedikit berbeda oleh guru kelas IV B mengenai mata pelajaran Bahasa Indonesia dalam Kurikulum 2013 bahwa Kurikulum 2013 masih banyak terdapat kesulitankesulitan baik itu dari sarana dan prasarana, pengetahuan guru serta penilaian yang begitu sulit.

\section{Saran-saran}

1. Kepala Sekolah adalah supervisi sekolah yang bertugas untuk memimpin seluruh kegiatan yang ada di sekolah, kepala sekolah yang bertugas menilai kurikulum seperti apa yang sesuai diterapkan di SD Negeri 02 Centre Curup.

2. Bagi guru meskipun pembelajaran yang ditawarkan Kurikulum 2013 berpusat pada siswa dan guru hanya sebagai fasilitatr, maka pembelajaran seperti itu tidak akan menurunkan kinerja guru dalam hal proses belajar mengajar

\section{DAFTAR PUSTAKA}

Arif, Memahami Pendidikan dan Ilmu Pendidikan, (Yogyakarta : Laks Bang Mediatama, 2009)

Chaer, Abdul, Tata Bahasa Praktis Bahasa Indonesia, (Jakarta: PT Rineka Cipta, 2000)

Daryanto, dkk, Siap Menyongsong Kurikulum 2013, (Yogyakarta : Gava Media, 2014)

Hakim, Lukmanul, Perencanaan Pembelajaran, (Bandung: Bumi Rancaekek Kencana, 2012)

Harmi, Hendra, Perencanaan dan Sistem Pembelajaran Kurikulum Tingkat Satuan Pendidikan (KTSP), (Curup :LP2 STAIN CURUP, 2010

Majid, Abdul, Implementasi Kurikulum 2013 Kajian Teoritis dan Praskti, (Bandung: Interes Media, 2014 )

Mulyati,Yeti dkk, Keterampilan Berbahasa Indonesia SD. (Jakarta : UniversitasTerbuka, 2009) 
Ngalimun dan Noor Alfulaila, Pembelajaran Keterampilan Berbahasa Indonesia, (Yogyakarta : Aswaja Pressindo, 2014)

Priyatni, Endah Tri, Desain Pembelajaran Bahasa Indonesia dalam Kuriklum 2013, (Jakarta :Bumi Aksara, 2014

Rosdiana,Yusi, Bahasa dan Sastra Indonesia di SD, (Jakarta: Universitas Terbuka, 2011)

Sani,Ridwan abdullah, Pembelajaran Saintifik untuk Implementasi Kurikulum 2013. (Jakarta : PT Bumi Aksara, 2014)

Sarwono,Sarlito Wirawan, Pengantar Psikologi Umum, (Jakarta: PT raja Grafindo Persada, 2013)

Sugiyono, Memahami Penelitian Kualitatif. (Bandung: Alfabeta, 2012)

Suharso dkk, Kamus Besar Bahasa Indonesia, (Semarang: Widya Karya, 2012)

Suyadi, Strategi Pembelajaran Pendidikan Karakter, (Bandung :PT Remaja Rosdakarya, 2013)

Tukiran, Tanireja dkk, Penelitian Tindakan Kelas untuk Pengembangan Profesi Guru, (Bandung : Alfabeta, 2010)

Tohaputra, Ahmad, Al-Qur'an dan Terjemahannya (Ayat Pojok Bergaris), (Semarang

Trianto, Desain Pengembangan Pembelajaran Tematik, (Jakarta : Kencana, 2011)

Trianto, Mendesain Model Pembelajaran Inovatif-Progresif. (Jakarta : Kencana Prenada

Dewi Sri Budi. Wawancara, Guru SDN 02 Curup

Sugih Riang. Wawancara. Guru SDN 02 Curup 
Estetik, Vol.2 No.1, Mei 2019

ISSN 2622-1810 (p) 2622-1829 (e) 